monthly temperature for five years (1903-8) varies from $9.68^{\circ} \mathrm{F}$. in July to $32.54^{\circ}$ in January, while the absolute range in the same period was $88^{\circ}$. The temperature variability of the seasons brings out the tendency to a winter continental and a summer oceanic climate. These values are (1904):-spring, $5 \cdot 1^{\circ}$; summer, $1 \cdot 3^{\circ}$; autumn, $5.4^{\circ}$; winter, $9 \cdot 1^{\circ}$. The year 1904 had a mean annual temperature of $22.4^{\circ}$, which is $0.96^{\circ}$ below the average mean of the five years $1903-8$.

The wind directions, which were taken from the movements of the lower clouds, since the high land to the west of the observatory tended to deflect many winds, show a prevalence of north-westerly winds. Subsequent years' observations give west and south-west winds as the most trequent, which seems to show that the readings of 1904 give too high a value to north-west winds. Undoubtedly the position of Omond House is such that west and southwest winds would tend to be below what would be recorded in an unexceptional situation. In fact, on further consideration, Mr. Mossman has, we understand, come to the conclusion that the wind directions of 1904 are not wholly trustworthy. East, and especially north-east, winds are conspicuously rare, and the percentage wind frequency for each season does not materially differ from that of the year. The temperatures associated with these winds are of great interest, but unfortunately in $\mathrm{Mr}$. Davis's five years' summary no thermal wind-roses are given. Very probably the high temperatures associated with some of these apparent westerly winds is partly due to Föhn effects, since in May, 1903, that is, in midwinter, an undoubted Föhn wind raised the temperature at the site of the observatory to $46^{\circ}$, which was only $x^{\circ}$ lower than the absolute maximum of the year.

Associated with these prevailing west and south-west winds, which were also experienced by Dr. Nordenskjold at Snow Hill in 1902-3, there exists a low-pressure area in the Weddell Sea, furthest south in autumn and most northerly in winter, but with a centre normally about $66^{\circ} \mathrm{S}$. and $30^{\circ}$ to $35^{\circ} \mathrm{W}$. The continental origin of these prevailing winds accounts largely for the low temperatures of the South Orkneys compared with their latitude. The thermal gradient on the east of Graham Land is steep, and this fact, in relation to the southward bending of the isotherms about $40^{\circ} \mathrm{W}$., is strong evidence for the existence of the northward projection of Antarctica south of the South Orkneys to about the Circle. Moreover, on no other grounds is it possible to account for the very low temperatures that occur from time to time at Scotia Bay with southerly and south-easterly winds.

\section{NATIVE WORKING OF COAL AND IRON IN CHINA.}

$A \mathrm{~N}$ interesting illustrated article on the native working of coal and iron in the province of Shansi, China, appears in Engineering for December 2. In the Ping Ting Chau districts the iron ore is of excellent quality. The methods of extraction are decidedly primitive; in the old workings the ground is often found honeycombed with small shafts. seldom more than $\mathbf{I} 4$ inches in diameter, and usually just large enough to allow a man to go down. The tools used consist of a native pick, a cast-iron hammer, a wedge, and a sort of basket-shovel, the ore being raised in the basket by a small wooden winch. The climate is healthy, but work under such conditions is sure to produce disease, and consumption is very prevalent. During the summer the mines are shut down, and all the men become farmers until the close of the harvest season. The southern district specialises in wrought-iron goods, for example, spades, picks, nails, wrought-iron bars, and general ironwork; the northern district produces the larger and rougher classes of goods, such as cast-iron pans and sections of tyres for cart-wheels. Reduction of the ore is conducted in roasting-kilns; the broken-up ore is mixed with anthracite and charged into clay crucibles, which are heated in the kilns for about four days. The iron residue is then treated in a foundry, where it is broken up and remelted in crucibles for the production of cast iron, or, if wrought iron is being produced, by melting in a crude furnace, hammering, and puddling.

The Ping Ting Chau district is one of the largest NO. 2 I47, VOL. 85$]$ anthracite coal beds of which there is any knowledge. The natives get at the coal by adit or by shaft, as may best suit the nature of the ground. Shafts vary from 6 to 8 feet in diameter, and from 60 to 300 feet in depth; the thickness of the seam of coal varies from 4 to 18 feet. During late years native mechanics have been giving advice, with the result that collieries are coming into existence in which the coal is hoisted in baskets, and cow-hide bags are used for hauling out accumulations of water. A Canton Chinaman attempted to apply up-to-date methods to a mine just outside the Ping Ting Chau area, and sank a shaft beside the adit. He proposed to use a winch for winding up the coal, but before this could be done water was struck and the mine flooded. Boilers and pumps were erected by Chinese workmen, and the water was successfully cleared out of the first level. Shortly after starting work an explosion took place, and practically closed the shaft. At present the men are carrying the coal up the steps in bags in an excessively high temperature due to the steampipes, and the Cantonese has retired from the field. Pick, hammer, and wedge are the only tools used.

\section{THE DYNAMICS OF A GOLF BALL.'}

THERE are so many dynamical problems connected with golf that a discussion of the whole of them would occupy far more time than is at my disposal this evening. I shall not attempt to deal with the many important questions which arise when we consider the impact of the club with the ball, but confine myself to the consideration of the flight of the ball after it has left the club. This problem is in any case a very interesting one; it would be even more interesting if we could accept the explanations of the behaviour of the ball given by many contributors to the very voluminous literature which has collected round the game; if these were correct, I should have to bring before you this evening a new dynamics, and announce that matter, when made up into golf balls, obevs laws of an entirely different character from those governing its action when in any other condition.

If we could send off the ball from the club, as we might from a catapult, without spin, its behaviour would be regular, but uninteresting; in the absence of wind its path would keep in a vertical plane; it would not deviate

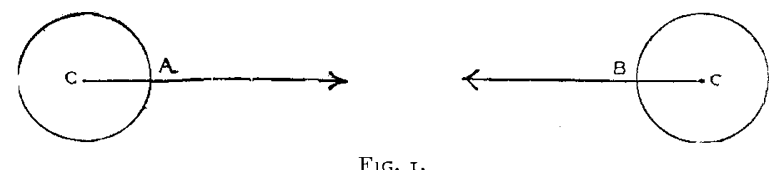

either to the right or to the left, and would fall to the ground after a comparatively short carry.

But a golf ball when it leaves the club is only in rare cases devoid of spin, and it is spin which gives the interest, variety, and vivacity to the flight of the ball. It is spin which accounts for the behaviour of a sliced or pulled ball, it is spin which makes the ball soar or "douk," or execute those wild flourishes which give the impression that the ball is endowed with an artistic temperament, and performs these eccentricities as an acrobat might throw in an extra somersault or two for the fun of the thing. This view, however, gives an entirely wrong impression of the temperament of a golf ball, which is, in reality, the most prosaic of things, knowing while in the air only one rule of conduct, which it obeys with unintelligent conscientiousness, that of always following its nose. This rule is the key to the behaviour of all balls when in the air, whether they are golf balls, base balls, cricket balls, or tennis balls. Let us, before entering into the reason for this rule, trace out some of its consequences. By the nose of the ball we mean the point on the ball furthest in front. Thus if, as in Fig. I, C the centre of the ball is moving horizontally to the right, $A$ will be the nose of the ball; if it is moving horizontally to the left, B will 1 Discourse delivered at the Royal Institution on Friday, March 18 , by Sir J. J. Thomson, F.R.S. 